\title{
ESPAÇOS PÚBLICOS E SEUS USUÁRIOS: PRAÇAS DE TERESINA
}

\author{
Isis Meireles \\ Centro Universitário UNINOVAFAPI \\ Prof. Ma. do curso de Arquitetura e Urbanismo - UNINOVAFAPI \\ isis@uninovafapi.edu.br \\ Marina Dos Santos Brasil Araújo \\ Graduanda em Arquitetura e Urbanismo - UNINOVAFAPI \\ ba_marina@hotmail.com \\ Jadiane Beilfuss \\ Graduanda em Arquitetura e Urbanismo - UNINOVAFAPI \\ jadi.beilfuss@outlook.com
}

\section{RESUMO}

O presente trabalho trata da Análise Pós Ocupacional no espaço público urbano, tendo como objeto de estudo diferentes praças localizadas na cidade de Teresina, capital do Piauí nordeste do Brasil, com recorte cronológico da correspondente aos dias atuais. A pesquisa é resultado de estudos realizados por discentes da disciplina de Práticas interdisciplinares: arquitetura e ambiente urbano, sob orientação da Prof. Ma. Ísis Meireles Rodrigues, docente do curso de Arquitetura e Urbanismo do Centro Universitário Uninovafapi. Esse estudo objetiva analisar diferentes espaços públicos urbanos abordando desde as características presentes no projeto ao uso pós-ocupacional. Buscou-se verificar a adequação ou inadequação dos espaços públicos urbanos existentes, auxiliando em intervenções futuras e realizando a leitura da cidade como sujeito passível de modificações constantes, redefinindo o tempo todo territórios, com suas continuidades e descontinuidades.

Palavras chaves: Espaços públicos, avaliação pós ocupacional, apropriação social.

\section{ABSTRACT}

This present work deals with the Post - Occupational Analysis in the urban public space, having as object of study different squares located in the city of Teresina, capital of Piauí northeast of Brazil, with a chronological cut of the one corresponding to the present days. The research is the result of studies carried out by students of the discipline of Interdisciplinary Practices: architecture and urban environment, under the guidance of Prof. Ma. Isis Meireles Rodrigues, lecturer in the Architecture and Urbanism course at Uninovafapi University Center. This study aims to analyze different urban public spaces, from the characteristics present in the project to the post-occupational use. It was sought to verify the adequacy or inadequacy of existing urban public spaces, assisting in future interventions and reading the city as a subject subject to constant modifications, redefining all the time territories, with their continuities and discontinuities.

Key words: Public spaces, post-occupational evaluation, social appropriation. 


\section{INTRODUÇÂO}

O presente trabalho possui como tema a Análise Pós Ocupacional no espaço público urbano, tendo como objeto de estudo diferentes praças localizadas na cidade de Teresina, capital do Piauí nordeste do Brasil, com recorte cronológico da correspondente aos dias atuais.

A cidade de Teresina é composta por 4 zonas: Zonas Centro-Norte, Sul, Sudeste e Leste, e frequentemente são analisados os espaços públicos localizados no centro da cidade. Assim, com o intuito de expandir essa área de estudo, os espaços públicos escolhidos, encontram-se em regiões distintas das demais zonas da cidade, além de situarem-se em bairros com características essencialmente residenciais. Pode-se então constatar a diferença ou não, do uso pós ocupacional, em relação a bairros com características comerciais. Deste modo, como observado na Figura 1, foram realizadas análises em seis praças: Praça Nossa Senhora da Imaculada Conceição, Praça Dom Avelar Brandão Vilela, Praça dos Correios, Praça Eldorado, Praça Renascença I e Praça Jornalista Carlos Castelo Branco.
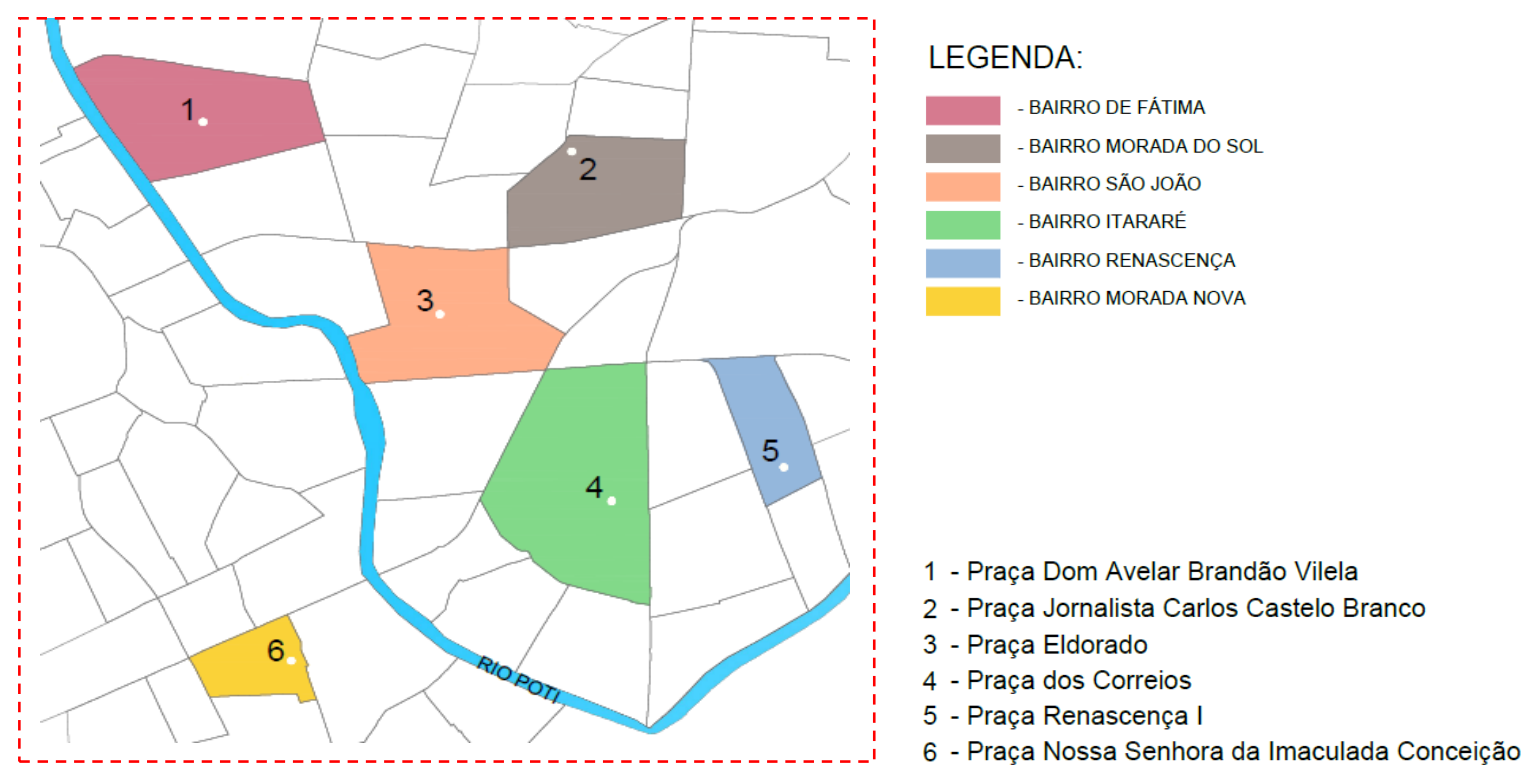

Figura 1: Localização dos objetos de estudo na cidade de Teresina Elaboração própria a partir de dados da SEMPLAN

O estudo objetivou analisar diferentes espaços públicos urbanos abordando desde as características presentes no projeto ao uso pós-ocupacional. Possui como objetivos específicos verificar a sua funcionalidade, o processo histórico de sua criação e a forma como se estruturam com a malha urbana na cidade, mostrando a preservação e conservação desse espaço público.

Para a construção do referencial teórico utilizou-se de autores como Jacobs (2000), Hillier (1984), Heitor (2011), Lamas (2010), Cullen (2009) entre outros. Nessa pesquisa, entende-se morfologia urbana como o estudo da forma das cidades, considerando concepções estéticas, ideológicas, culturais ou arquitetônicas, definindo e explicando a paisagem urbana (Lamas, 2010). Hillier (1984) apresenta conceitos presentes na teoria da sintaxe espacial como a teoria do movimento natural desenvolvida para compreender a utilização do espaço pelos usuários através de análise de fluxo. A sintaxe espacial é aqui compreendida como a busca do traçado e a relação entre o espaço privado e o público através de estudos estatísticos que dão a compreensão sobre os aspectos urbanos, tais como a distribuição do uso do solo, coesão e exclusão social, acessibilidade, segurança, e áreas comerciais. De acordo com Netto (2013) a sintaxe espacial é capaz de apontar problemas e razões das falhas de projetos e ideologias urbanísticas, e dar o esperado apoio científico às intervenções projetuais.

Sabe-se que cidade é o espaço transformado pelas necessidades, objetivos, aspirações e exigências de um grupo ou pessoa em determinado momento. A análise visual serve para a compreensão de como os lugares são percebidos, sabendo que não há como entender cidade sem entender também o espaço e seus atributos visuais e as atividades realizadas no local (Heitor, 2011). 
Nessa pesquisa considera-se Praça qualquer espaço público urbano que está associado à ideia de haver prioridade ao pedestre e ajardinamento (Macedo e Robba, 2002). É livre de edificações e propicia convivência e/ou recreação para seus usuários. Usada funcionalmente como ponto de encontro, apreciação da paisagem, dispõem ao lazer da população, como: bancos para descanso, quiosques com vendas de lanches, barras de ginástica, pistas de caminhada e ciclovias, parquinhos para crianças, entre outros. Tem um papel importante na identidade o município, rua ou bairro e contribuem nas qualidades plásticas - cor, textura, forma, na estética e simbologia. Para Lamas (1993), a praça é um elemento morfológico das cidades ocidentais, inexistentes anteriormente, distinguindo-se de outros espaços, que são resultado acidental de alargamento ou confluência de traçados. Com o intuito de atrair o maior número de tipos de pessoas, em diferentes horários e interesses, as praças costumam incluir quatro elementos em seu projeto, como a complexidade, centralidade, isolação e delimitação espacial (Jacobs, 2000).

Atualmente vive-se uma época de reformulação do espaço urbano onde é visível a divisão em segmentos da sociedade, onde algumas construções concretizam esse processo, assim ampliando conflitos sociais urbanos. Esses conflitos se mostram através do desrespeito e depredação dos bens comuns, acarretando que o espaço público deixa de ser atraente para a população, tornando-se antiquado, nem por isso menos indispensável. Muitas vezes ocorre a não adequação do espaço às modificações do entorno, que, de maneira inevitável, transformam o tipo de usuário ou a relação do usuário com o espaço público, fazendo-se imprescindível o estudo das relações entre usuários e espaço edificado.

\section{HIPÓTESES}

O desenvolvimento da pesquisa, realizada por discentes do curso de Arquitetura e Urbanismo do Centro Universitário UNINOVAFAPI durante a disciplina de Práticas interdisciplinares: arquitetura e ambiente urbano, sob orientação da Prof. Ma. Ísis Meireles Rodrigues, partiu de um questionamento central, sobre Qual a relação entre os espaços públicos urbanos e a cidade? A partir dessa problemática inicial, outras questões se fizeram presente para a compreensão da evolução dos objetos de estudo, tais como: De que maneira os usuários percebem os espaços públicos urbanos em questão? Quais as condições históricas que possibilitaram mudanças de forma e uso nesses locais? Como esses locais são atualmente utilizados pela população?

O trabalho baseia-se na hipótese que a apropriação social dos usuários nos espaços públicos urbanos reflete suas adequações ou inadequações formais e espaciais. Portanto, se faz necessário, para esclarecer as questões expostas acima e a partir da análise dos dados coletados verificar a adequação ou inadequação dos espaços públicos urbanos existentes, auxiliando em intervenções futuras e realizando a leitura da cidade como sujeito passível de modificações constantes, redefinindo o tempo todo territórios, com suas continuidades e descontinuidades.

\section{METODOLOGIA}

A metodologia utilizada baseou-se em autores como Ornstein et al. (1995) focada na aplicação de questionários além da pesquisa histórica através do levantamento bibliográfico. Buscou-se realizar a Análise Sintática do Espaço, obedecendo as etapas representação, quantificação, observação e correlação do comportamento usuários no ambiente da praça e qual a sua relação com o equipamento. Realizou-se, portanto, pesquisa de campo composta por análise das propriedades espaciais da praça como barreiras, aberturas, espaços privados, espaços cegos, equipamentos urbanos, buscando identificação de barreiras, permeabilidades, acessibilidade além de aplicação de questionário objetivando verificar perfil e satisfação do usuário. Na construção do Perfil e satisfação do usuário utilizou-se a aplicação de questionários de entrevistas estruturados com perguntas relativas a construção e identificação dos seguintes aspectos: Perfil do usuário, frequência e motivação de uso do espaço, atividade realizada no local, meio de acesso, avaliação geral do ambiente, etc. As observações in loco também resultaram em construção de mapas de fluxos, mapeamento de pessoas paradas e permanência de usuários, verificando por onde as pessoas caminham dentro do equipamento público; de onde as pessoas vêm e para onde elas vão; onde são os locais de o fluxo é mais intenso; realizando zoneamento de acordo com os usos; identificação de práticas indesejáveis; verificação da correspondência entre a estrutura espacial e os usos. 
Para o mapeamento das pessoas paradas realizou-se observação durante ao menos dois dias na semana, em horários pré definidos em pelo menos dois turnos distintos. Realizou-se a marcação das pessoas paradas em intervalos de 5 minutos durante 20 minutos. Para o mapeamento das pessoas em movimento, buscou-se verificar os percursos realizados e utilizou-se a estratégia dos Gates. A contagem de pessoas ocorreu em portais determinados (gates) e durou 5 minutos em horários definidos para os dias da semana, também em dois turnos. A partir dessas observações desenvolveram-se os mapas e gráficos utilizados nos diagnósticos da pesquisa.

\section{CASOS}

\subsection{Praça Nossa Senhora da Imaculada Conceição}

Para desenvolvimento dos estudos que se seguem, acessou-se os resultados da pesquisa realizada pelos alunos Naylla Silva, Ana Angélica Santos, Stella Rodrigues e Samuel Nascimento intitulada Análise do espaço público: a relação socioespacial e cultural na praça Nossa Senhora da Imaculada Conceição em Teresina, apresentado como requisito avaliativo da disciplina Práticas Interdisciplinares: arquitetura e ambiente urbano, sob orientação da Prof. Ma. Isis Meireles. A Praça Nossa Senhora da Imaculada Conceição está localizada na Zona Sul da cidade de Teresina, no Bairro Morada Nova, como observa-se na Figura 2.

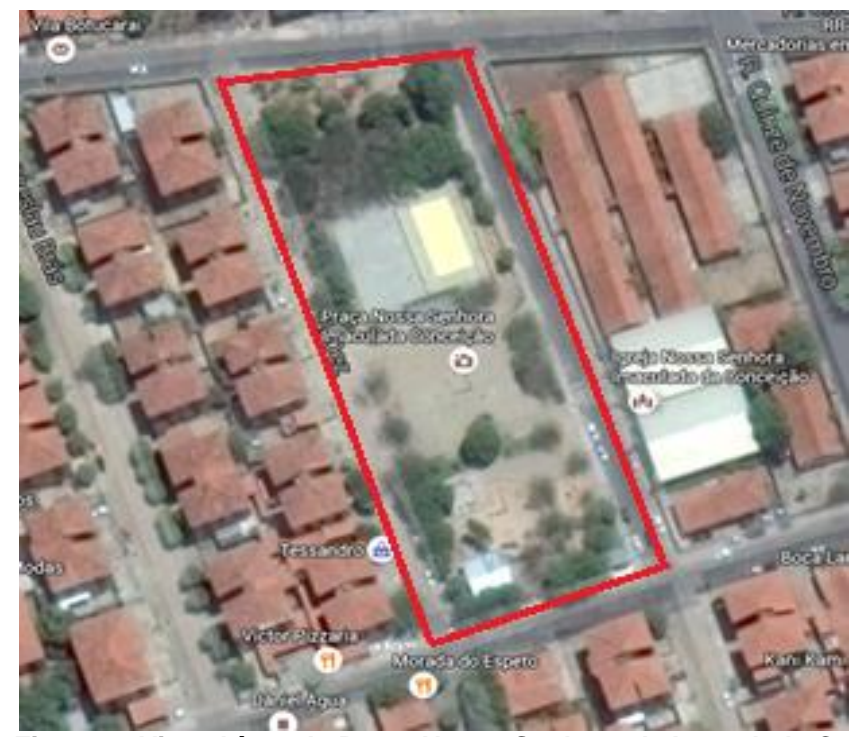

Figura 2: Vista Aérea da Praça Nossa Senhora da Imaculada Conceição (Nascimento, 2016 com dados do Google Earth)

A praça Nossa Senhora da Imaculada Conceição encontra-se localizada em um dos primeiros conjuntos habitacionais verticais na capital, o conjunto Morada Nova, além de estar próximo a Paróquia do mesmo nome. Foi fundada em 1987, a partir da construção realizada pela a Cohab (Companhia de Habitação do Piauí), no bairro Morada Nova, de um dos primeiros conjuntos de habitações verticais de Teresina. Antes chamado de Morada Nova I, em 1990 foi ampliado com o Morada Nova II e III, hoje o bairro é um dos que apresenta maior densidade populacional da capital (Semplan, 2013). A execução do projeto da praça ficou a cargo da Empresa Teresinense de desenvolvimento, durante o mandato do prefeito Heráclito Fortes (19891993). A praça, em sua primeira tipologia, era caracterizada pelo piso de cimento tradicional, com pouca iluminação e alguns bancos. Logo depois, foi feita a construção das quadras de vôlei e futsal. Teve sua primeira reforma em 1998, com a construção de um palco para apresentações culturais e artísticas, e, já no ano de 2008, foi feita a substituição do piso de cimento por granilite. Em 2015, foi composta com uma academia popular e playgrounds (Prefeitura de Teresina,2015). Atualmente verifica-se a presença de bancos, complexo esportivo como a quadra de vôlei e futsal, um palco para apresentações artísticas e culturais, academia popular e playground. Encontram-se várias tipologias e diferentes portes de árvores, tais como mangueira, árvores de médio porte e forrações como a grama-esmeralda nos canteiros. Há apenas uma rampa em toda a praça, limitando o acesso à mesma. A quadra esportiva encontra-se fechada com uma mureta baixa e com cercas em cima, permitindo a permeabilidade visual das pessoas. Já o palco 
que serve para apresentações tem uma parede no fundo que se torna uma barreira visual, assim como os trailers comerciais existentes. Além disso, as árvores de grande porte dificultam a apreensão do espaço.

O entorno da Praça em questão é composto essencialmente por residências, existindo também comércios, academia, delegacia, escola, Igreja e Paróquia. Jacobs (2000) afirma que praças situadas em áreas basicamente residenciais, limita os horários de uso dos usuários da praça. Com esses diferentes usos, percebeu-se que o fluxo das pessoas muda em diferentes dias e horários. Através dos mapas de portas e janelas notou-se a predominância de residências muradas que pela tarde maioria das portas e janelas residenciais do entorno permanecem fechadas, e os comércios abertos, já ao anoitecer observa-se que a maioria das janelas das residências estão abertas e as portas fechadas, mas o comércio continua aberto. Tem a predominância de casas muradas por causa da sensação de insegurança, que vai de encontro ao pensamento de Jacobs (2000) que fala sobre a permeabilidade do entorno e a sensação visual de segurança nos usuários.

Como resultado dos questionários aplicados, verificou-se que a grande parte dos frequentam a praça é do sexo feminino, com predominância de idade entre 22 a 30 anos, e em menor número entre 16 a 21 anos. As pessoas utilizam a praça mais pela procura do esporte (com $50 \%$ dos resultados) pelo turno da manhã e tarde, com baixa permanência de usuários à noite. Como modo de locomoção, a maioria do público chega ao local a pé. O maior índice de reclamação é a insegurança (70\%) e limpeza. Com menor porcentagem encontram-se reclamações de iluminação.Com a observação feita com pessoas paradas e 0 que estão fazendo, percebeu-se que pelo horário da tarde as pessoas estão, dentre outras atividades, assistindo TV, conversando, trabalhando, malhando, observando e até aguardando o transporte coletivo, com predominância de pessoas bebendo, trabalhando ou em pé conversando. Já pelo turno da noite, um maior número de usuários encontra-se trabalhando ou perto da academia popular fazendo suas atividades físicas, percebendo-se assim que a academia é um item atrativo de usuários, como observado na Figura 3.

PESSOAS PARADAS

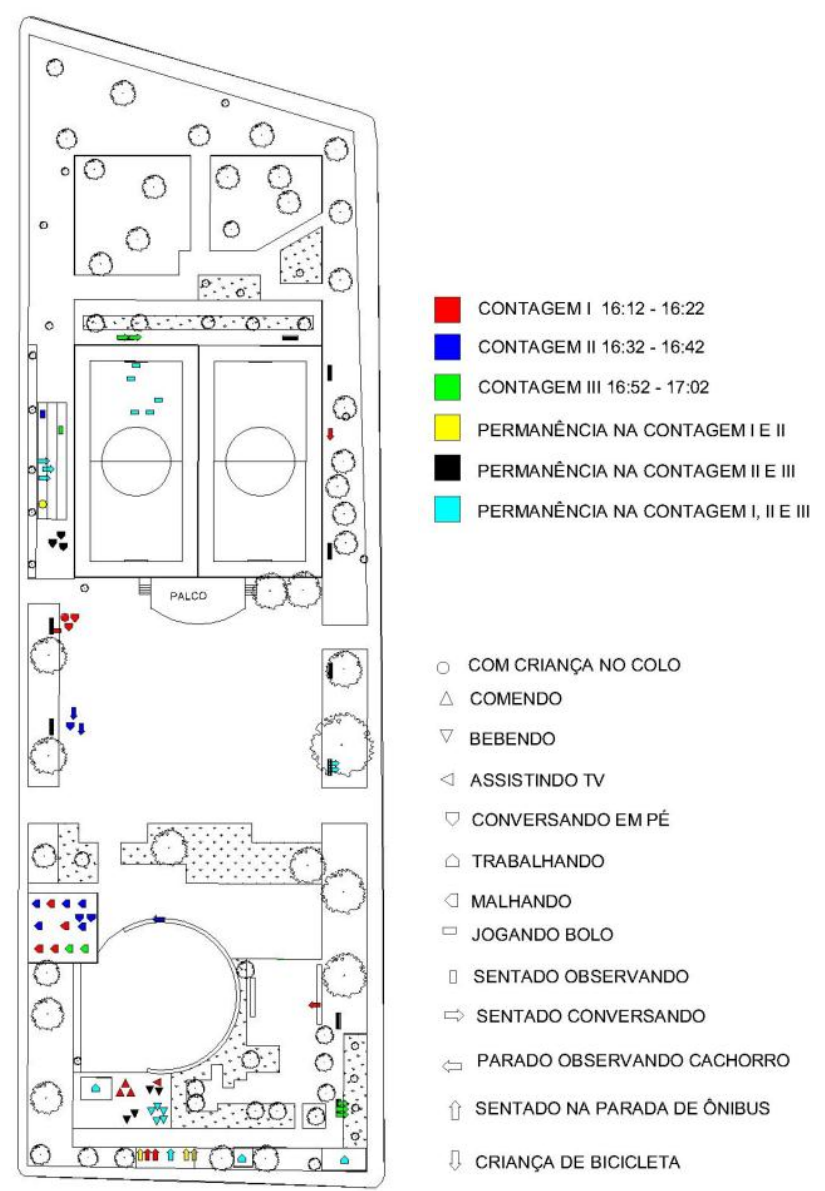

FLUXOS

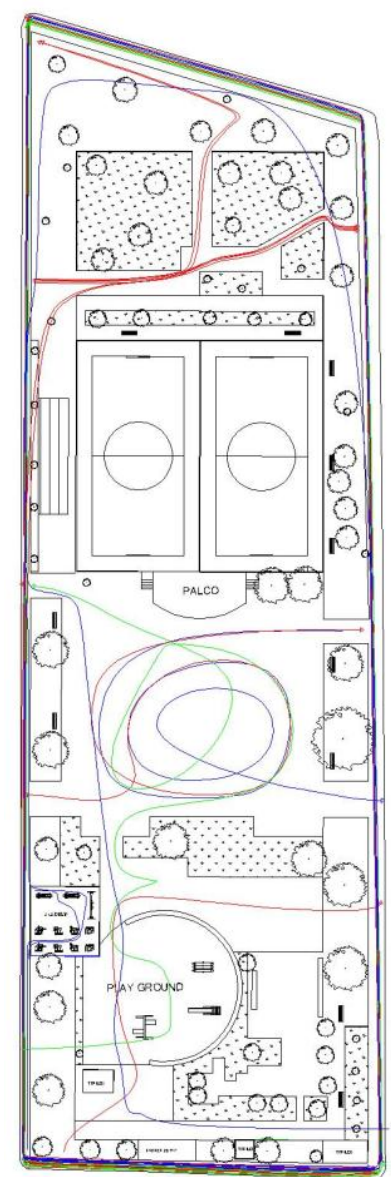

CONTAGEMI 16:30 - 1640

CONTAGEM II 16:50 - 17:00 CONTAGEM III 17:10 - 17:20

Figura 3: Mapeamento Pessoas Paradas e fluxos no turno da tarde (Moura, 2016) 
Quando observado o fluxo das pessoas, vê-se que pela tarde tem-se um fluxo regular ocasionado pelo uso da academia e atividades esportivas como caminhadas e passeio com cachorros. Há presença de crianças andando de bicicletas, brincando ou jogando futebol é mais significativa. Durante a noite, o movimento é mais relacionado ao comércio existente na praça e no entorno, aumentando a apropriação quando há alguma missa ou festividade da Igreja.

Verifica-se portanto que a Praça Nossa Senhora da Imaculada Conceição tem como atrativo o lazer com a presença de playground, comércio com os trailers e prática de atividades físicas como caminhadas ou com a academia popular existente, além de quando há missas da Igreja ao lado, atrator natural de pessoas. Mesmo após reformas, a praça precisa de uma série de melhorias, com prioridade a iluminação. As calçadas em alguns pontos estão em estado ruim, assim comprometendo a acessibilidade. O playground encontra-se em estado precário, podendo haver substituição desses brinquedos, já que há uma grande frequência de crianças no local.

Durante as pesquisas, foi sugerido pelos moradores do bairro a criação de um local apenas para os animais. A praça ainda é considerada insegura para as pessoas que utilizam, que, mesmo com câmeras de vigilância ainda apresenta um número relevante de assaltos, havendo a necessidade de guardas policiais para coibir as práticas delituosas. Quanto a vegetação, mesmo havendo grande quantidade de árvores, carece de forrações para um melhor conforto e estética.

\subsection{Praça Dom Avelar Brandão Vilela}

A praça Dom Avelar Brandão Vilela está localizada na Avenida Nossa Senhora de Fátima, no Bairro de Fátima, na Zona Leste da cidade de Teresina (Figura 4)

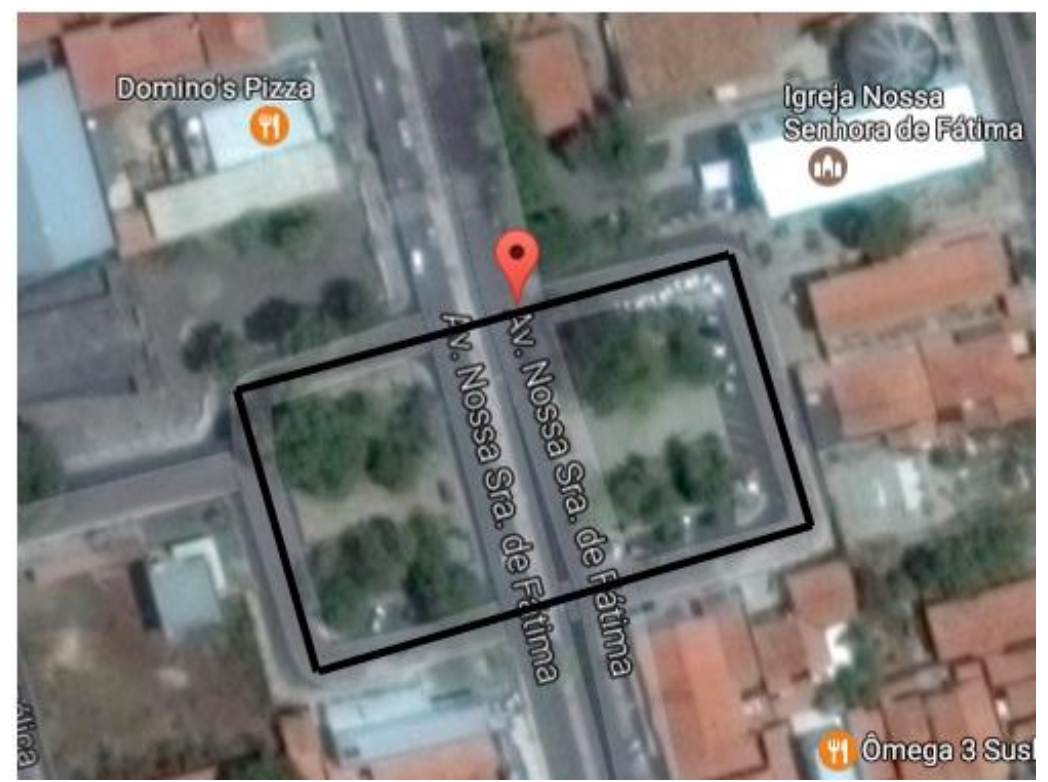

Figura 4: Vista Aérea da Praça Dom Avelar Brandão Vilela (Autoras, 2016 com dados do Google Earth)

Ao analisar a praça Dom Avelar Brandão Vilela observou-se que é um símbolo na cidade de Teresina, por ser considerada uma praça privada da Paróquia da Igreja Nossa Senhora de Fátima, Igreja essa bastante conhecida e frequentada na cidade. Outro ponto observado é que a praça está localizada na Avenida Nossa Senhora de Fátima, uma avenida importante e muito movimentada por estar situada na Zona Leste da capital. O bairro onde a mesma se localiza originou-se na metade da década de 1950, a partir da construção do Jockey Clube do Piauí, em uma área da cidade antes desabitada. Essa ocupação foi proporcionada pela construção da ponte Juscelino Kubitscheck em 1957, permitindo a expansão da cidade para além da margem direta do Rio Poti. 
O espaço em análise era utilizado para cultivo de alimentos e, posteriormente, foi equipada com equipamentos urbanos e iluminação. Hoje o seu entorno além de ter a Paróquia, possui pontos comerciais, de entretenimento e de uso educacional (Sousa et al, 2016).

Em relação as barreiras e permeabilidades, a Praça Dom Avelar Brandão Vilela possui uma boa visibilidade, calçamento em bom estado de conservação, porém há barreiras visuais devido aos trailers existentes no local. A praça possui apenas duas rampas, uma em cada lado da praça, acarretando dificuldades na acessibilidade (Sousa et al, 2016).

Observou-se a predominância de usuários do sexo masculino, adultos e em menor número, apenas $9 \%$ idosos. Grande parte dos usuários utiliza a praça nos turnos diurno e vespertino com predominância de mais acesso através do transporte coletivo. $66 \%$ das pessoas acham a praça acessível por estar localizada em uma avenida de grande fluxo. A principal reclamação é a insegurança, seguido da limpeza e iluminação. Atualmente no local observa-se a presença de bancos, paradas de ônibus, ponto de táxi, postes de iluminação pública, lixeiras, trailers, placas de sinalização vertical, além de estacionamento. Existem diversas tipologias de arvores, de pequeno a grande porte, como também há presença de palmeiras, arbustos e gramíneas. No entorno da Praça encontram-se algumas residências em desuso, terrenos vazios, escola e a Paróquia Nossa Senhora de Fátima, cujas portas e janelas permanecem, durante os períodos da manhã e da tarde, em sua maioria, fechadas (Sousa et al, 2016).

Durante as visitas a praça, foram realizados mapas de atividades realizada por pessoas parada (Figura 5), e notou-se que ficam trabalhando, conversando e observando enquanto aguardam o transporte coletivo.

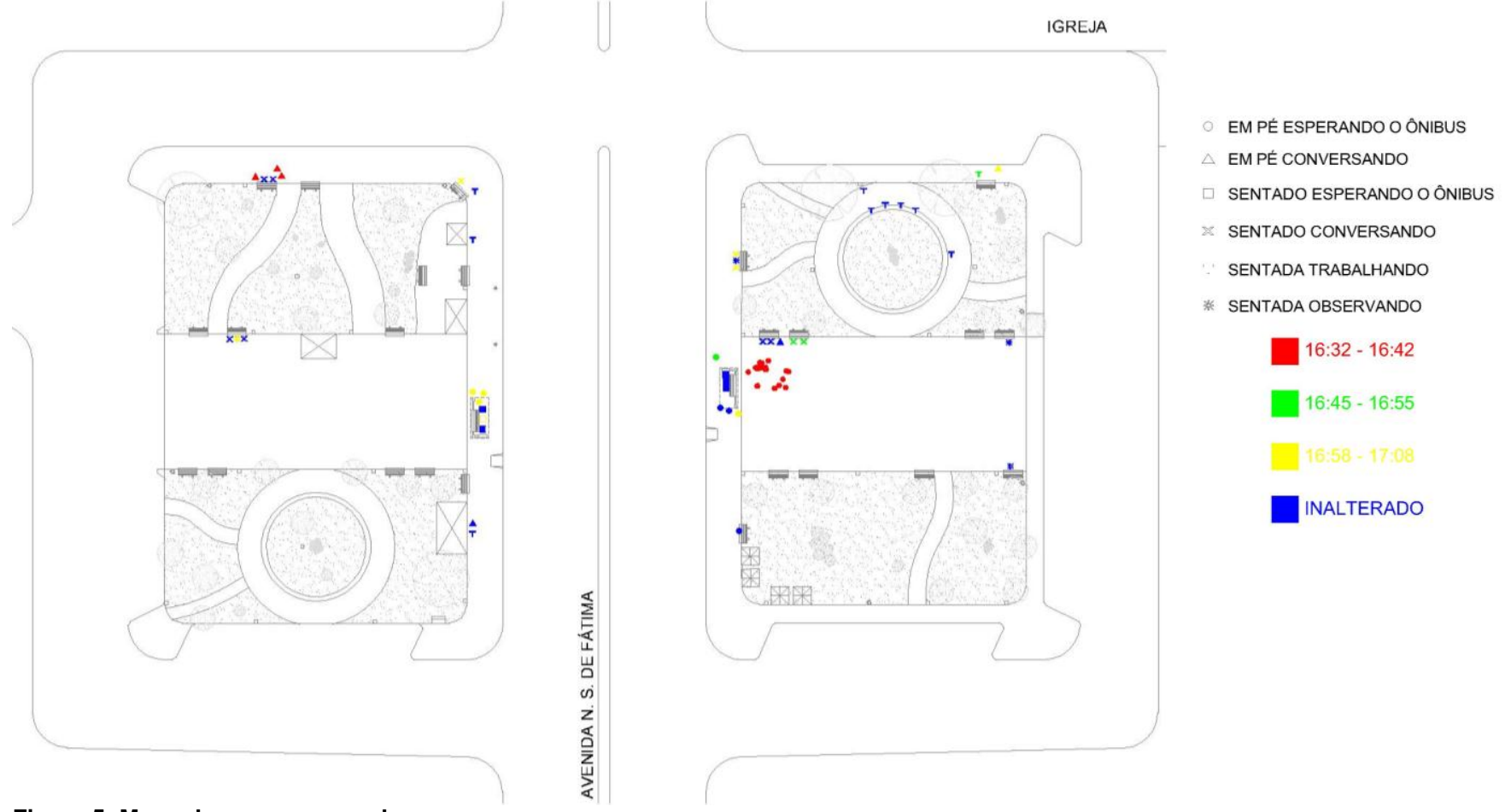

Figura 5: Mapa de pessoas paradas

(Sousa et al, 2016)

Com a realização dos mapas de fluxos realizado no mesmo dia que foram observadas as pessoas paradas (Figura 6), observou-se que o maior fluxo da praça é próximo à Avenida Nossa de Fátima devido ao movimento em direção à parada de ônibus. Outro ponto de atração para as pessoas é a Paróquia, existindo um fluxo intenso em direção a mesma. Verificou-se, devido a intensa circulação de pessoas e diversidade de usos a sensação de segurança apontada pela população é maior, apesar de a mesma possuir espaço residencial e terrenos vazios. 


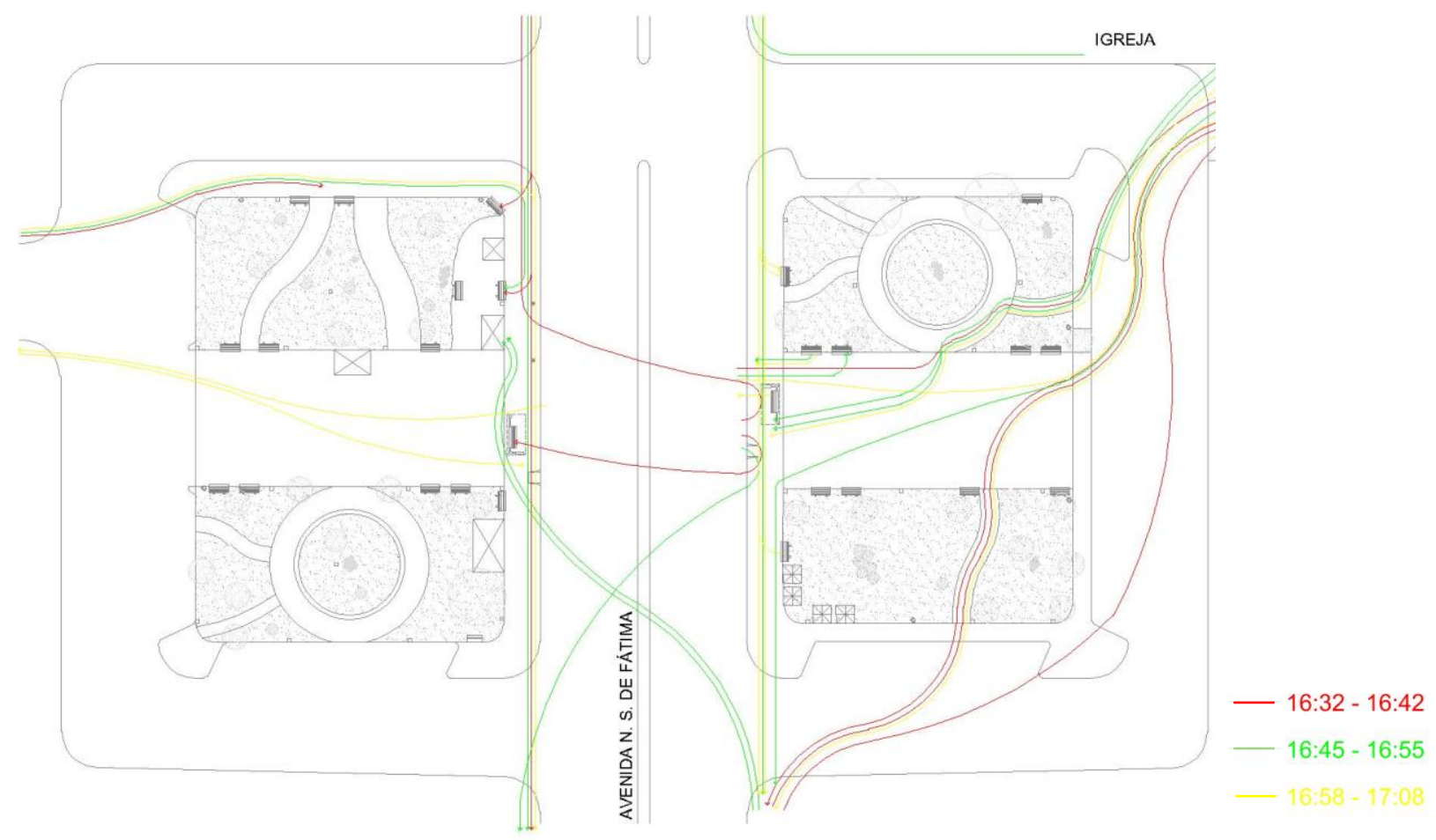

Figura 6: Mapa de fluxos

(Sousa et al, 2016)

Diante dessas situações atuais da praça apesar de ter a Paróquia no entorno, é preciso modificar a parte do entorno da praça abandonada, melhorá-la na iluminação pública, na segurança, como também adequar as paradas de ônibus que se encontram deterioradas, juntamente com os equipamentos urbanos, pois segundo Jacobs (2000) quando não há permeabilidade visual no entorno os equipamentos urbanos acabam se inutilizando pela falta de uso ocasionado pela insegurança.

\subsection{Praça dos Correios}

A Praça dos Correios localiza-se na Avenida Principal do Dirceu no Bairro Dirceu II, Zona Sudeste de Teresina, conforme figura 7 .

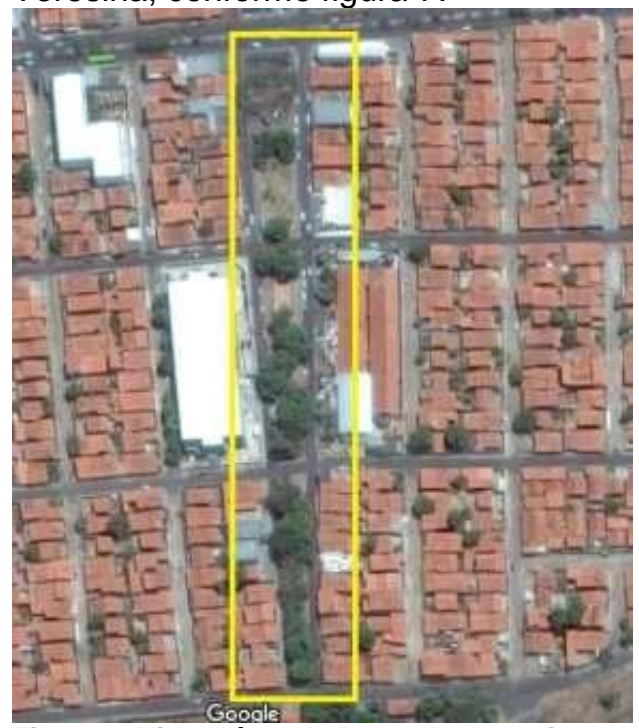

Figura 7: Vista Aérea da Praça dos correios

(Costa et al, 2016 com dados do Google Earth) 
Ao analisar a Praça dos Correio em relação a cidade de Teresina, nota-se então que a Praça dos Correios é considerada um local relevante para o bairro onde se insere, pois esta está em frente a locais de trabalhos de uma parte da população, é local de passagem para alguns e permanência e lazer de outros, além de estar localizada em uma das áreas mais populosas da capital. O Bairro Dirceu II nasceu da ocupação de uma área que pertencia à Fazenda Itararé, de Pedro de Almendra Freitas. O Bairro abrangia também as terras do Sítio São Raimundo Nonato, de José Camilo da Silveira. Tornou-se o bairro mais populoso de Teresina após a construção do conjunto Dirceu Arcoverde construído pela COHAB. Segundo a Semplan, (2014, apud Costa et al, 2016) em 2010 o bairro Itararé representava quase $5 \%$ da população da cidade de Teresina, assim ocupando a primeira posição. Nos últimos anos a taxa populacional reduziu mais de $8 \%$. Entre os equipamentos urbanos existentes na Praça observam-se muitos bancos distribuídos, lixeiras, trailers de diferentes tipos de venda, academia popular, além de quadra de esporte e playground. Há presença de árvores de variadas tipologias, que variam de grande, médio e pequeno porte, além de palmeiras fênix, no centro da praça, Neen Indiano, a Palmeira Pati, entre outras espécies (Costa et al, 2016).

O entorno é composto por edificações de maioria residencial, possuindo também centros comerciais, instituições de saúde e empresas privadas, com isso segundo Jacobs (2000) essa praça por se predominar o entorno residencial acaba limitando os horários de uso dos usuários da praça. Foi observado nas edificações, voltadas para a praça, que pela manhã a maioria das janelas estão fechadas e porta abertas, já pela noite a maior parte das janelas e portas estão fechadas. Percebe-se, portanto, uma maior sensação de insegurança no período noturno (Costa et al, 2016). A pavimentação da Praça dos Correios encontra-se deteriorada, com muitos desníveis, dificultado a passagem dos pedestres, além de não haver rampas, assim comprometendo a acessibilidade. A praça possui pouca permeabilidade visual, causada pela presença de variados quiosques/trailers na praça e pelas árvores de grande porte (Costa et al, 2016). A maior parte dos frequentadores são do sexo feminino, predominando pessoas com mais de 45 anos, e poucas pessoas entre 26 a 45 anos. Com $50 \%$ dos visitantes frequentam a praça pelo lazer, já que há quadra de esporte e playground, e usam o ônibus como modo de locomoção de acesso à praça. A maioria dos usuários moram no próprio bairro e mais da metade do grupo analisado considera a praça acessível e com $50 \%$ das pessoas consideram o local inseguro (Costa et al, 2016). Durante a análise de fluxos e pessoas paradas (Figura 8) e o que estão fazendo foi observado que pelo horário da manhã o público encontra-se comendo, observando, conversando, assim como durante a noite, porém, nesse horário vê-se uma concentração maior de usuários nos trailers existentes na praça.
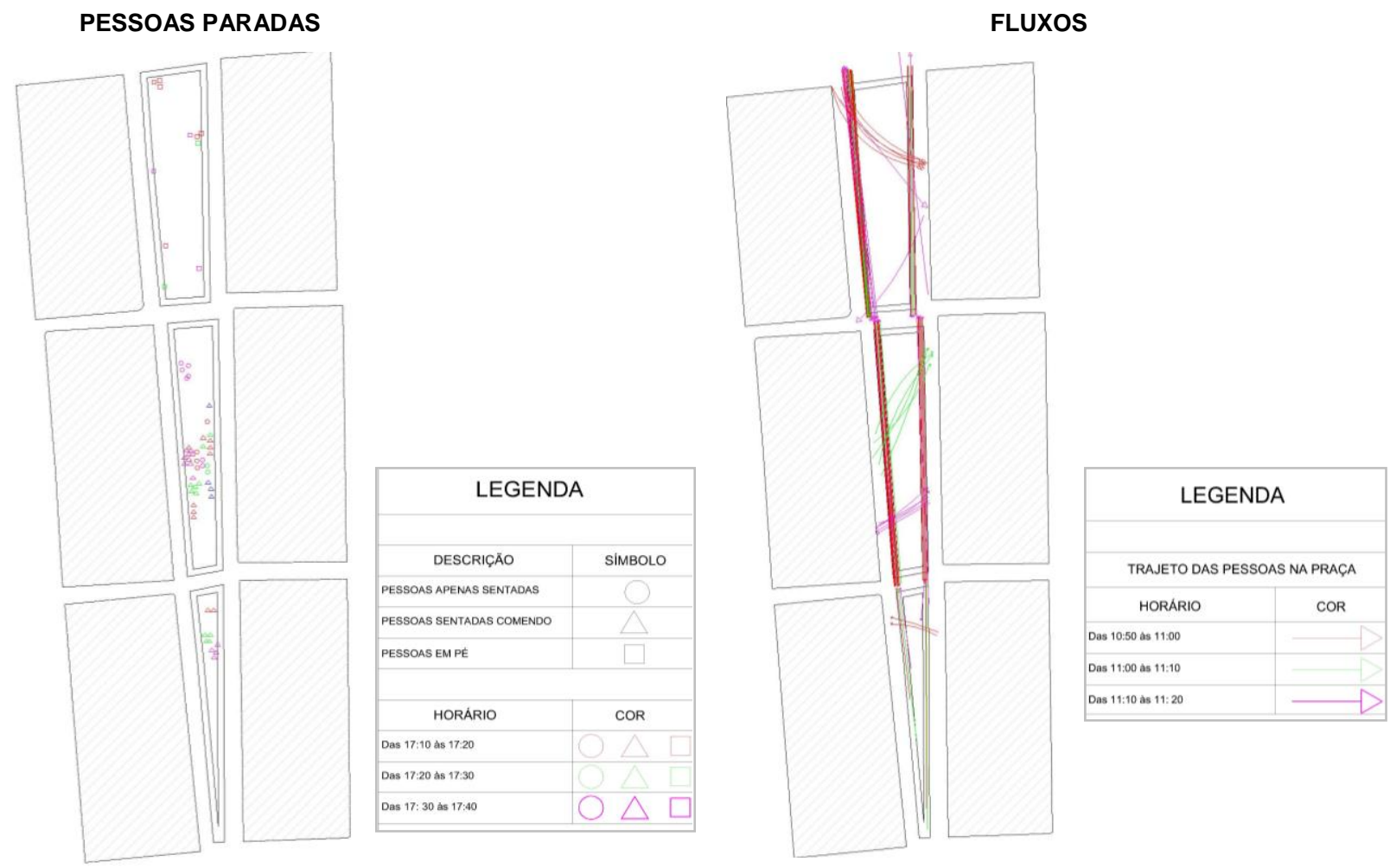

Figura 8: Mapa de pessoas paradas e fluxos no turno da manhã (Costa et al, 2016) 
Ao realizar o mapa de fluxo de cada turno, foi visto que pelo horário da tarde tem um grande fluxo de pessoas pela praça devido à saída dos postos de trabalho, ocasionando maior movimento no espaço público. Já pelo turno da noite o fluxo se intensifica pela presença dos pontos de alimentação e bares inseridos dentro da praça.

O piso da praça encontra-se desgastado, com desníveis que prejudicam a acessibilidade, além de não haver rampas acessíveis. Há acumulo de lixos em determinadas áreas da praça, por não existirem lugares definidos para dejetos, necessitando de lixeiras. Uma das maiores críticas relatada pelos usuários é a falta de segurança, seguida da iluminação ineficiente.

\subsection{Praça Eldorado}

A Praça Eldorado (Figura 9) está localizada na Zona Leste de Teresina, no Bairro São João, entre a Avenida Noronha Almeida, Rua Salomão Said, Rua Sete e Rua Fernando Pires Leal. Este espaço torna-se um marco na cidade de Teresina, devido à presença ao seu entorno de dois locais conhecidos pela população teresinense, a Paróquia João XXIII e o Eldorado Country Club. O bairro possui como um de seus limites a rodovia estadual PI-112, conhecida como Av. João XXIII, sendo extremamente movimentada, e em contrapartida, a praça fica ao lado de uma Zona Especial de Reserva de Área Urbana (ZE6), assim, buscouse constatar se há ou não algum impacto no uso pós ocupacional da praça devido esses aspectos.

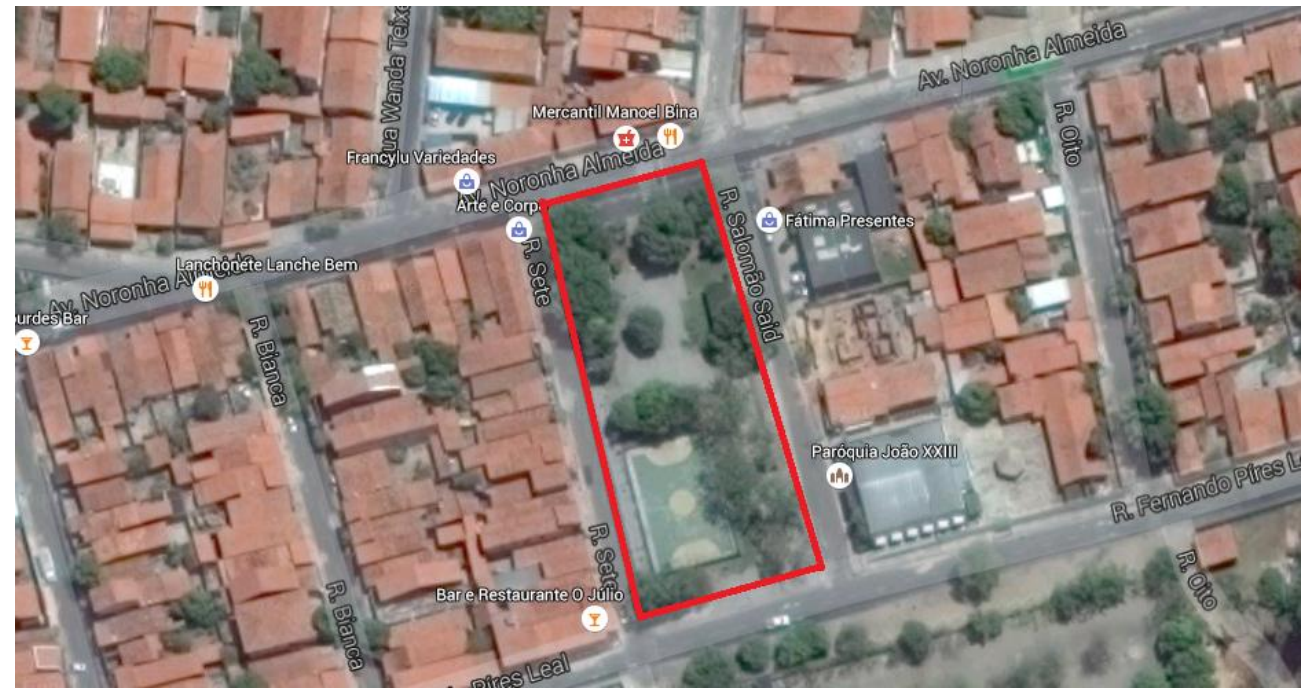

Figura 9: Vista aérea da Praça Eldorado

(Dias et al, 2016 com dados do google earth)

De acordo com a SEMPLAN (2014), o bairro São João surgiu através do loteamento Giovane Prado, localizado próximo à Avenida João XXIII. Inicialmente, a região possuía muitas palmeiras e o bairro era conhecido como Macacal. O limite do bairro era entre a Rua Miguel Nascente e a Avenida dos Expedicionários. Em 1988, devido o planejamento de Teresina, esse limite diminuiu, passando a ser da Rua Pires Gaioso até a Avenida dos Expedicionários (Dias et al, 2016).

O espaço público da praça é composto por uma lanchonete, uma banca de jornal, uma quadra, um playground, além dos jardins e árvores, de suma importância para a integração da praça e dos moradores locais. Em relação à vegetação, identificou-se algumas espécies, entre elas, podemos citar a Gramaesmeralda, Mangueira, Oiti e Pau d'Alho. O calçamento da praça encontra-se conservado, entretanto as quatro rampas existentes estão mal distribuídas e não há vagas de estacionamento para portadores de necessidades especiais. Há apenas uma faixa de pedestre, ligando a praça à parada de ônibus localizada na avenida, ocasionando grande deficiência de acesso dos pedestres nas demais ruas (Dias et al, 2016).

Outro aspecto que deve ser observado, são os quatro quarteirões que circundam a praça, sendo dois mais estreitos e dois mais alongados formando um tecido urbano que ocasiona certa dificuldade de permeabilidade e percepção. Jacobs (2000), defende que as quadras curtas geram diversidade urbana, havendo assim, alternativas de percursos e possibilitando fluxos nas ruas que, de outra maneira, permaneceriam desertas. $O$ acesso de pedestres é facilitado onde a praça é delimitada por ruas locais, 
devido o menor fluxo de veículos, o que não é observado na lateral onde há uma avenida com duas faixas de rolamento de veículos (Dias et al, 2016).

Ao entorno da praça, encontram-se edificações residências e comerciais, parada de ônibus, área de lazer denominada Clube Eldorado e uma Paroquia, a qual possui missa todos os dias, exceto nas segundasfeiras. Segundo Jacobs (2000), devido ao uso misto do entorno da praça torna-se atrativo a presença de diferentes usuários, em horários distintos, e devido seus diversos compromissos, além de quase sempre ter um movimento continuo.

Durante a manhã, observou-se que as portas dos comércios encontram-se abertas, e nas residências a maioria das janelas também, entretanto muitas de suas portas estão fechadas. No período da tarde, há predominância de janelas e portas abertas, tanto em edificações residências quanto comerciais. No final da tarde, as portas dos comércios e em parte considerável das portas e janelas das residências, ainda se encontram abertas, devido o costume dos moradores sentarem-se nas portas de casa ao entardecer para conversar e observar o movimento (Dias et al, 2016).

Após a coleta de dados e análise dos mesmos observou-se que o sexo e faixa etária dos usuários da praça é bem distribuída. Grande parte dos frequentadores é do sexo masculino, e possuem de forma decrescente, entre 50 e 60 anos, seguido de 20 e 30 anos, de 30 a 40 anos, de 10 a 20 anos, e com menor porcentagem, são pessoas com mais de 60 anos. Observa-se que a maioria dos usuários frequenta a praça diariamente, e mais da metade dos mesmos realiza seu deslocamento até a Praça Eldorado a pé. $97 \%$ dos entrevistados afirma que o espaço, possui acessibilidade e apontam como pontos negativos a iluminação, ausência de recreação, falta de estrutura e insegurança (Dias et al, 2016).

$\mathrm{Na}$ observação de pessoas paradas conforme a Figura 10, verificou-se durante a manhã a presença de pessoas sentadas na praça, algumas vendendo mercadorias (CD e DVD's). No período da tarde, houve crescimento do número de pessoas presentes no local. Enquanto crianças brincavam, as mães ficavam sentadas no banco conversando ou usando o celular. Ao anoitecer observou-se as pessoas reunidas no local para conversar, lanchar nas barracas de comida (Dias et al, 2016).

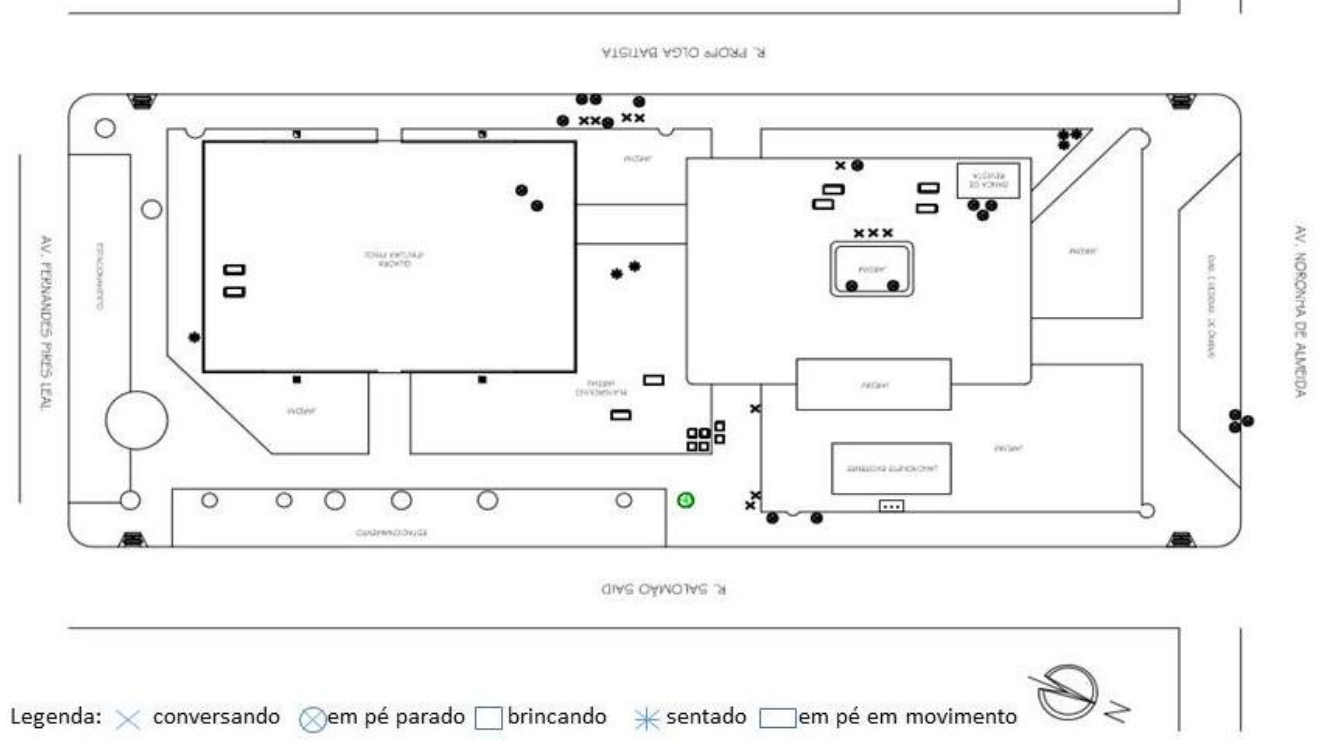

Figura 10: Mapa de pessoas paradas no turno da noite

(Dias et al, 2016)

Ao analisar-se as pessoas em movimento (Figura 11), percebe-se, no período da manhã, um baixo fluxo de pessoas, onde alguns usuários estavam apenas de passagem. Durante a tarde, constata-se o crescente número de pessoas, verificando-se a presença de crianças brincando no playground, adultos fazendo caminhada ao redor da praça e/ou praticando exercícios físicos. Ao anoitecer, cresce de maneira significativa o fluxo de pessoas na praça, muitas delas vestidas para prática de esportes, devido o funcionamento de uma academia no Clube Eldorado neste horário. Além disso, embora a praça não possua uma academia popular, a população à utiliza frequentemente para prática de atividades físicas. 


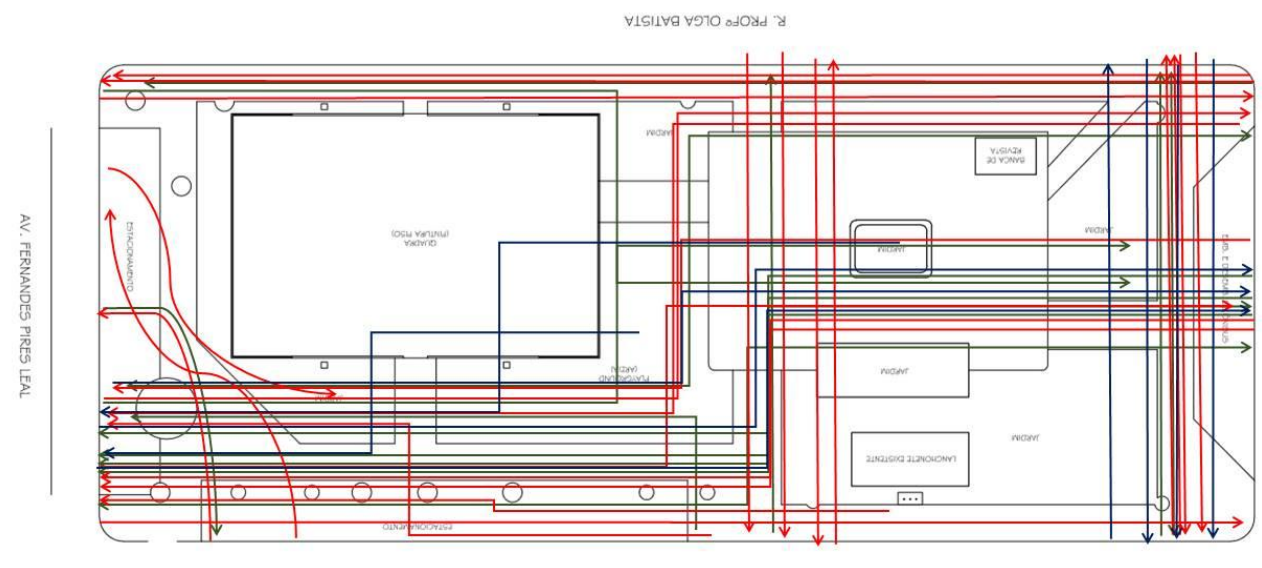

arys Oywotys 'y
LEGENDA:

$\longrightarrow$-DAS 18H ATÉ 18:10H

-DAS 18:20H ATÉ 18:30H

-DAS 18:40H ATÉ 18:50H

Figura 11: Mapa de fluxos da Praça Eldorado (Dias et al, 2016)

A Praça Eldorado é frequentada diariamente em todos os horários e é considerada bem localizada pelos entrevistados, devido ao bairro em que se insere e a existência da igreja no entorno. Por outro lado, é notória a falta de conservação, acessibilidade, segurança, equipamentos urbanos e iluminação na praça, tornando-se reclamações frequentes dos usuários do espaço. Segundo o Semplan (2016), uma proposta de reforma e melhorias da Praça Eldorado foi desenvolvida, porém não foi executado até o momento. A falta de manutenção frequente da vegetação é perceptível, devido à predominância de ervas daninhas nos jardins. Em relação à segurança, apesar da considerável movimentação e uso frequente, os usuários ainda se sentem inseguras na praça, fazendo com que alguns evitem estar e/ou permanecer no local, o que entra em contradição com a visão de Jacobs (2000) que afirma que a presença de pessoas atrai outras pessoas. Deste modo, é necessária a implantação de uma melhor iluminação, fazer com que os imóveis do entorno tenham maiores aberturas voltadas para a praça, e assim possa servir para os moradores observar qualquer movimento suspeito no local, além sugerirem a implantação de um posto policial (Dias et al, 2016).

\subsection{Praça Renascença I}

Para desenvolvimento dos estudos que se seguem, acessou-se os resultados da pesquisa realizada pelos alunos Amanda Almeida, Anselmo Santos Neto, Beatriz Barbosa, Josilene Gonçalves e Zayla Silva, intitulado O papel da praça como espaço público - caso da praça do Renascença l em Teresina -PI e apresentado como requisito avaliativo da disciplina Práticas Interdisciplinares: arquitetura e ambiente urbano sob orientação da Prof. Ma. Isis Meireles.

Praça Renascença I, identificada na Figura 12, mais conhecida como Praça do Renascença I, localiza-se na cidade de Teresina, no bairro Renascença I, na região do grande Dirceu, zona sudeste do município, sendo delimitada pelas ruas Santa Rita de Cássia, Rua Padre Malagrida e Rua Senador Valdemar Santos. A Praça Renascença I foi implantada no centro do bairro, possibilitando assim, que os moradores pudessem usufruir do espaço com maior facilidade, devido sua menor distancia de deslocamento até o espaço. Além disso, o Bairro Renascença I, faz parte do Grande Dirceu que possui aproximadamente a população de $10 \%$ da capital, assim torna-se importante a analise desta praça devido sua presença nesta relevante região de Teresina. 


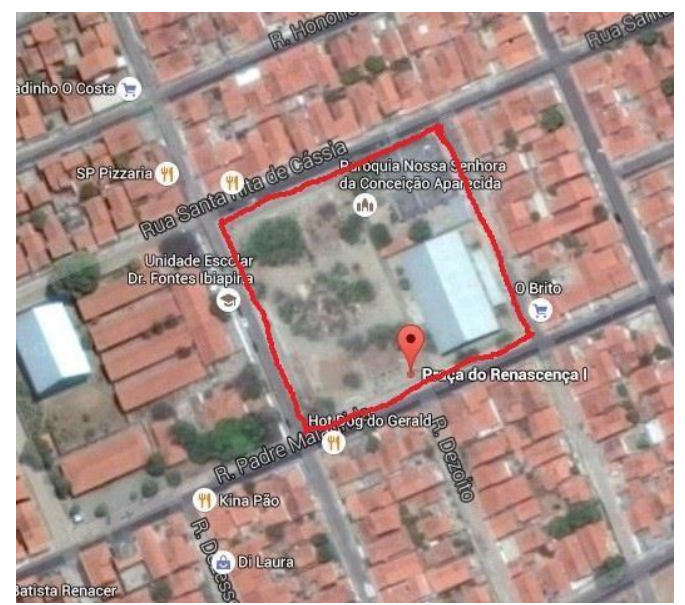

Figura 12: Vista Aérea da Praça Renascença I

(Almeida et al, 2016)

O bairro criado em 1978, se denominava Itararé, mas foi modificado após a morte do ex-governador do Piauí Dirceu Mendes Arcoverde (1975-1978), para homenageá-lo devido aos trabalhos desempenhados naquela região. Apesar da mudança do nome dos bairros para Dirceu Arcoverde I e II, o antigo nome Itararé ainda persiste na memória de muitos moradores.

Atualmente a área que se chama Itararé, é o bairro que abrange o Conjunto Habitacional Dirceu Arcoverde (I e II) e as residências construídas em seus arredores como o Renascença I. A Praça Renascença I possui como equipamentos urbanos, postes de iluminação, bancos, lixeiras, rampa de acesso e piso tátil para deficientes, ponto de moto taxistas, jardins, playground, além de espaço para a realização de atividades voltadas para a Terceira ldade. De acordo com a vegetação, identificou-se algumas espécies nativas encontradas, entre elas, o Oiti.

O entorno da praça é composto por edificações residenciais, comerciais e uso institucional, como a igreja, a escola, o centro comunitário e a quadra poliesportiva. Durante o dia, ocorre o funcionamento da escola e das atividades comerciais, de tarde podem ser realizadas atividades com crianças na igreja, e no final da tarde os bares começam a funcionar. Entretanto, como Jacobs (2000) afirma, praças localizadas em áreas predominantemente residenciais, ou com qualquer uso específico e predominante ao entorno da praça, acaba limitando os horários de uso, o que verificou-se no caso analisado devido à presença da igreja, da escola e de muitas residenciais ao entorno da praça. A igreja e a quadra de esportes localizam-se na lateral da quadra, dificultando a visão dos moradores do entorno para a praça, e consequentemente sua permeabilidade. Por esse motivo, mesmo sem a pavimentação adequada, as pessoas caminham em sentido diagonal na praça, principalmente da lateral onde se localiza a escola e o centro comunitário, onde está o ponto de moto taxistas e próximo aos bares. Devido à falta de segurança, todas as casas voltadas para a praça são muradas ou fechadas totalmente através de um portão e/ou porta, e não há abertura de janelas. Além disso, a fachada da escola possui grande extensão e é totalmente murada. Deste modo, segundo Jacobs (2000), as praças acabam possuindo o mesmo problema que as ruas sem olhos, as quais ganham fama de perigosas e são evitadas. Além disso, seus equipamentos acabam se deteriorando não pelo desgaste de uso, mas por tornarem-se alvos de vandalismo.

Através da realização de entrevistas, constatou-se que a Praça Renascença I, possui maior presença de pessoas do sexo feminino, é utilizada principalmente por moradores do próprio bairro, e os demais entrevistados estavam apenas de passagem em direção a outro local. Em relação à faixa etária, percebe-se que há uma boa distribuição de pessoas de todas as idades na praça, sendo de forma decrescente, visitantes com 21 a 30 anos, 15 a 20 anos, 31 a 40 anos, 41 a 50 anos, 51 a 60 anos, 0 a 15 anos, e por último, usuários com mais de 60 anos. De acordo com os usuários, as árvores não obstruem a visão da população para a praça, entretanto os entrevistados estão insatisfeitos com a estética das espécies da vegetação existente. Além disso, a população também se questiona pela falta de melhoria nos equipamentos como o playground, devido seu atual estado precário, e pela insegurança durante a manhã e à noite, devido baixa movimentação e iluminação ineficiente da praça.

No início da manhã, os usuários da praça utilizam a academia para prática de atividades físicas. Com o passar do tempo, principalmente os homens, permaneciam embaixo da coberta de madeira conversando, e 
o outros estavam no ponto de moto táxi localizado sob uma árvore em uma das extremidades da praça (Figura 13). O movimento da praça se intensifica à tarde, devido às atividades desenvolvidas na quadra por volta das $16 \mathrm{~h}$, quando aulas de dança aeróbica são realizadas para o público feminino, além da utilização da academia aberta por homens e mulheres.

Notou-se um maior fluxo (Figura 14) no sentido diagonal devido à dificuldade encontrada para atravessar a praça e passar entre a igreja e a quadra, assim como não há espaço suficiente para circulação de pessoas entre a praça e a igreja e/ou entre a praça e a quadra.

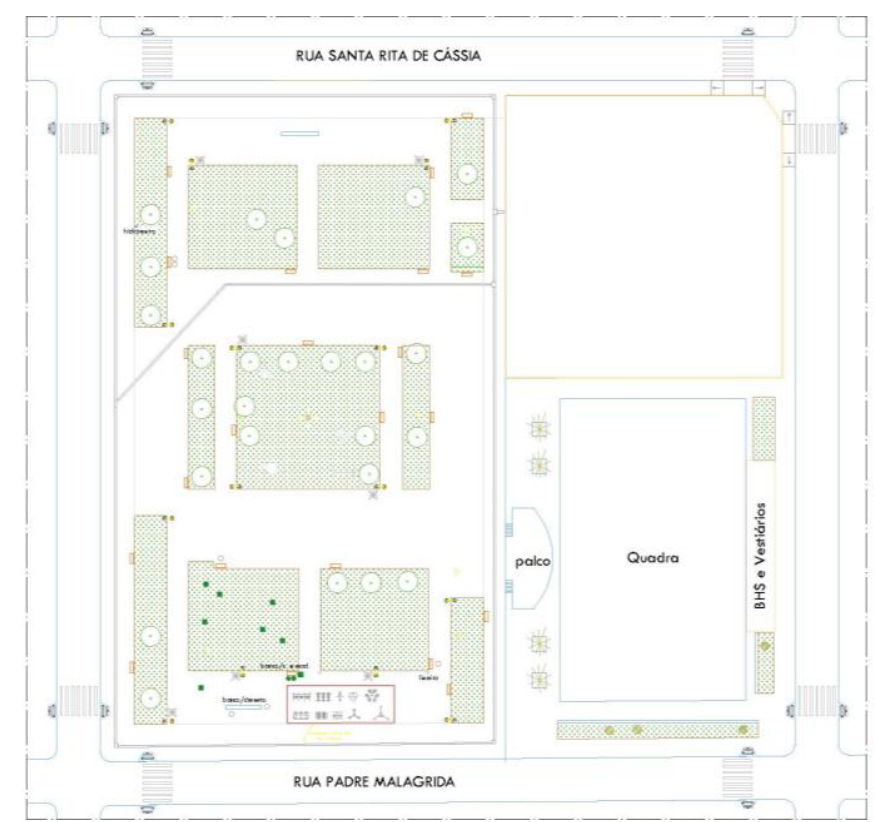

LEGENDA

PESSOAS PARADAS (comendo, bebendol, PESSOAS PARADAS ( lendo, escrevendo, PESSOAS PARADAS (interagindo de pé) PESSOAS PARADAS (observando)

Figura 13: Mapa de pessoas paradas no turno da tarde

(Almeida et al, 2016) 


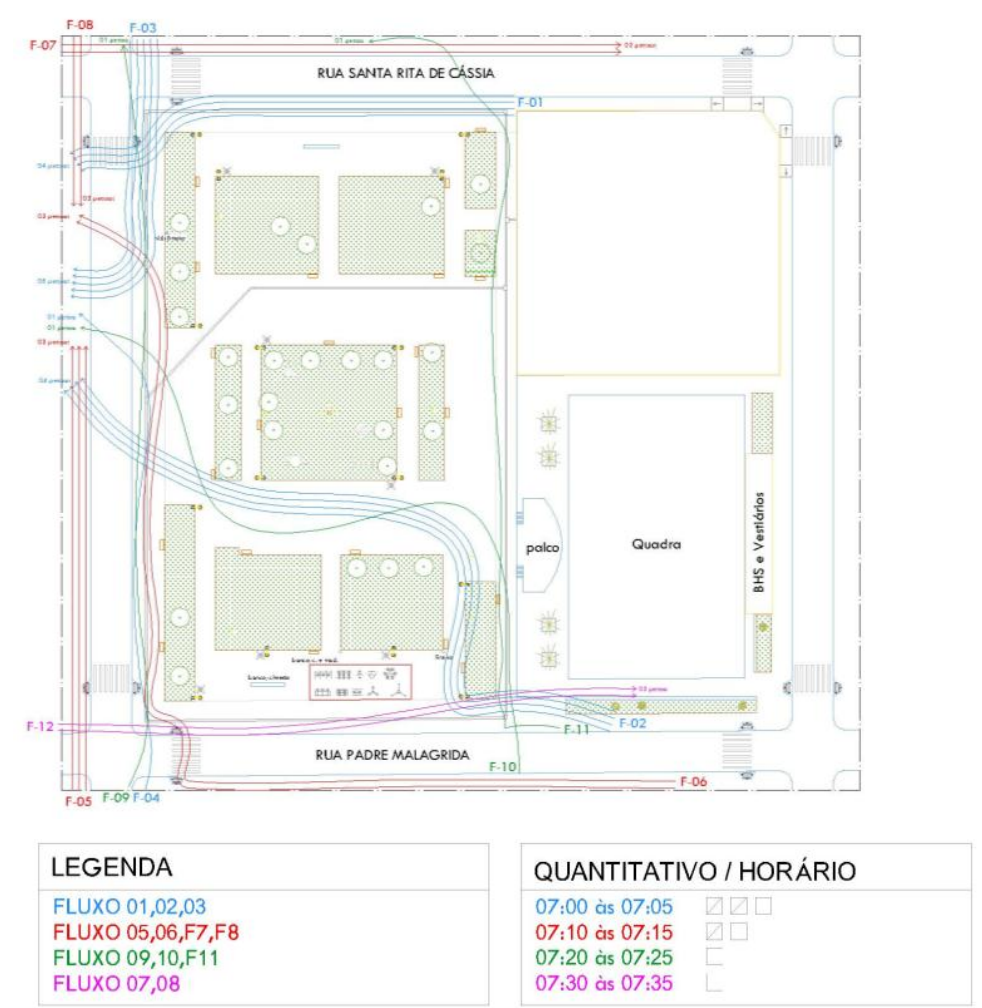

Figura 14: Mapa de fluxos no turno da tarde

(Almeida et al, 2016)

Ao realizar o estudo da Praça Renascença I, identificaram-se modificações sugeridas pelos usuários da praça, entre elas a melhoria na segurança, nos equipamentos urbanos, nas atividades culturais, na iluminação, tornar a vegetação mais densa e realizar a limpeza adequada do local. A insegurança relatada pelos usuários se deve à falta de infraestrutura básica, como iluminação eficiente, policiamento constante e uso frequente do espaço. O momento com maior público diariamente na praça e maior segurança, é no horário vespertino devido à utilização do espaço para aulas aeróbicas.

Assim, para a praça ter de volta sua função social bem estabelecida, é necessário que seja dado a ela um uso efetivo. Podendo ser dedicada, a cada horário, uma atividade onde seja fundamental a participação da comunidade, além de promover a atração dos moradores pela implantação de projeto paisagístico bem elaborado.

\subsection{Praça Jornalista Carlos Castelo Branco}

Para desenvolvimento dos estudos que se seguem, acessou-se os resultados da pesquisa realizada pelos alunos Ana Pacífico, Ana Liberato, Camilla Moura, Raqueline Sousa, Ravena Pereira e Thiago Landim, intitulado Praça Jornalista Carlos Castelo Branco e apresentado como requisito avaliativo da disciplina Práticas Interdisciplinares: arquitetura e ambiente urbano sob orientação da Prof. Ma. Isis Meireles. A Praça Jornalista Carlos Castelo Branco (Figura 15) está localizada no quarteirão delimitado pela Rua Azar Chaib, Rua Jaime da Silveira, Rua Dr. Jesus da Cunha Araújo e Rua Orlando Carvalho, no Bairro Santa Isabel, Zona Leste da cidade de Teresina (Cavalcante et al, 2016).

Analisando a praça Jornalista Carlos Castelo Branco no cenário teresinense, percebe-se que a praça fica localizada no ponto de entrelaçamento entre os Bairros Santa Isabel, Morada do Sol e Campestre. Desde modo, usuários diversos podem usufruir deste espaço público. Outro aspecto a ser observado, é que a praça localiza-se no final da Av. Dom Severino, sendo esta uma via arterial da cidade, e diversas ruas e a Av. Aquiles Wall Ferraz, vem ao seu encontro, tornando um espaço atrativo para pessoas que cruzam o espaço, seja de ônibus, bicicleta, a pé, ou de carro. Além disso, as duas avenidas e a Rua Jaime da Silveira, possuem um grande fluxo de ônibus, levando ao Centro Universitário Uninovafapi, tornando assim, a praça conhecida por muitos teresinenses e principalmente pelo público jovem. 


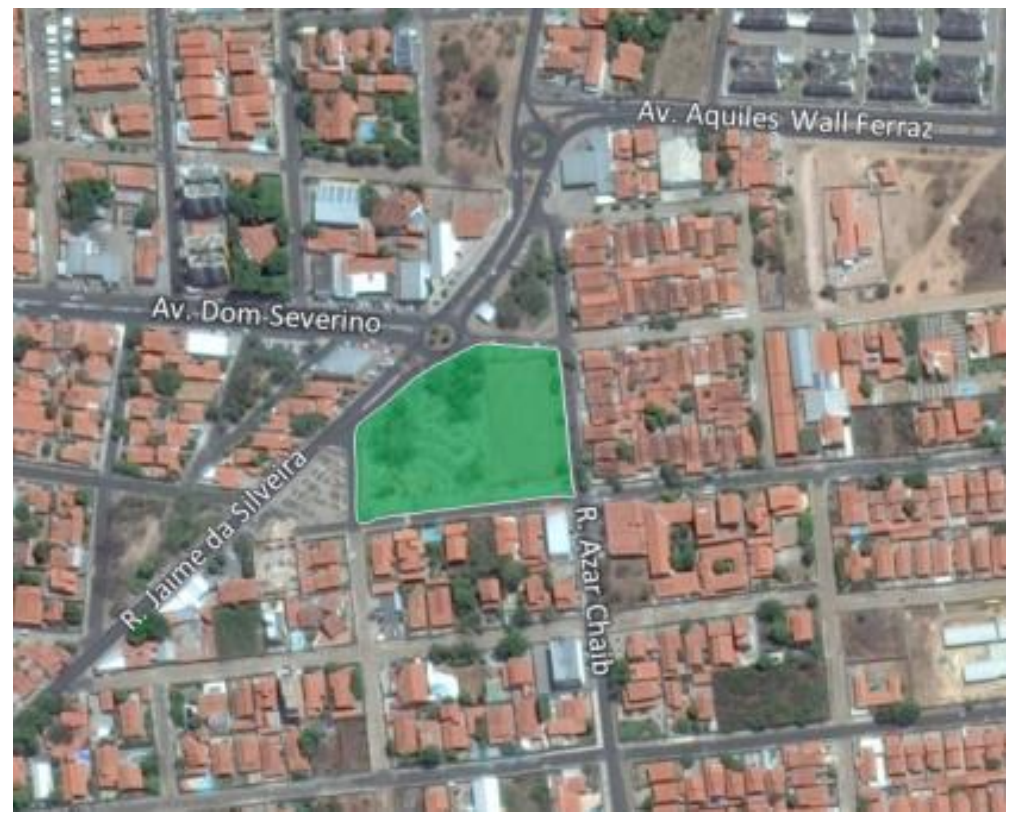

Figura 15: Vista Aérea da Praça Jornalista Carlos Castelo Branco

(Cavalcante et al, 2016 com dados do Google Earth)

O loteamento que deu origem ao Bairro Santa Isabel, foi um dos maiores loteamentos de Teresina e pertencia à ilustre família do Piauí de Dona Isabel Tajra, que the deu o nome de Santa Isabel. O bairro compreende a área contida no perímetro que começa no entroncamento da Av. João XXIII com a Rua Antonieta Ferraz, segue, por esta, até a Rua Jaime da Silveira, continua até a Av. Aquiles Wall Ferraz, em sentido leste, atinge a Av. Zequinha Freire, pela qual prossegue até a Av. João XXIII e daí, retorna ao ponto de partida. A fundação da Praça Jornalista Carlos Castelo Branco em 1982 está associada ao processo de loteamento do seu entorno, resultado da parceria entre a prefeitura e o Dr. Jorge Tajra. O nome da praça foi dado em homenagem ao jornalista e escritor piauiense Carlos Castelo Branco, um dos maiores comentaristas políticos da imprensa brasileira, membro da Academia Brasileira de Letras e da Academia Piauiense de Letras.

No projeto de divisão dos lotes, foi inserida a praça dedicada à área de lazer, devido a obrigatoriedade pelo Plano Diretor vigente na época. Inicialmente, a área dominada por vegetação nativa e carente de infraestrutura, não tinha condições de habitação. Na época, a construção da única via de chegada aos lotes ocorreu devido à necessidade de acesso à casa própria erguida pelo engenheiro, conectando a Avenida Dom Severino ao seu lote. Após dois anos, o Padre Monsenhor Melo solicitou a construção da Igreja do São Cristóvão no entorno da praça. Segundo o engenheiro Odimar da Costa, em 1994, ocorreu a pavimentação das ruas que delimitam a praça, porém ela foi efetivamente construída apenas em 2001, e passou por uma pequena reforma alguns anos depois (Cavalcante et al, 2016).

A Praça é utilizada para promover lazer, comércio, práticas esportivas, atividades religiosas e como passagem, constatando o caráter multifuncional da mesma. Possui uma quadra de esportes, bancos de concreto, estacionamento, um pequeno palco para eventos, um monumento, jardins, postes de iluminação e lixeiras para coleta seletiva. Foram observadas diversas espécies vegetais no local, dentre elas, o Oiti, ipê amarelo e Angico preto (Cavalcante et al, 2016). A praça apresenta boa permeabilidade visual, porém algumas barreiras visuais são causadas pela vegetação, pela mureta ao redor da quadra de esporte, pelas lixeiras de grande porte e pelos quiosques/pontos comerciais localizados na praça. Quanto à estrutura física e conservação, observa-se que a estrutura da praça é aceitável. Por outro lado, o mesmo não pode ser afirmado quanto à acessibilidade, pois o índice de satisfação é baixo, uma vez que não segue as normas de acessibilidade no que tange às rampas e a pavimentação (Cavalcante et al, 2016).

O entorno da praça é predominantemente residencial, sendo constituído também por pontos comerciais localizados principalmente na Av. Dom Severino, uma avenida importante da cidade, além de edificações religiosas e praças que se encontram próximas à praça (Cavalcante et al, 2016). Grande parcela das residências apresenta muros, devido à insegurança dos moradores na região. Além disso, a maioria das 
portas e janelas voltadas para a praça encontram-se fechadas, dificultando a visão entre os moradores das edificações e a praça. As edificações comerciais estão com as portas abertas, devido à necessidade de acesso direto e fácil dos usuários ao local. Nas proximidades da Praça Jornalista Carlos Castelo Branco, estão localizados outros espaços públicos (figura 15), e segundo Jacobs (2000), parques bem sucedidos, raramente tem concorrência de outras áreas livres, pois a população com a sua rotina, dificilmente consegue dar vida a uma quantidade ilimitada de praças locais de uso genérico.

Os usuários são em sua maioria são do sexo masculino e com ensino fundamental incompleto. Quanto à faixa etária, percebe-se que a maioria dos usuários possui entre 16 a 25 anos, e de forma decrescente é seguida de pessoas acima dos 50 anos, após isso, pessoas entre 35 a 50 anos e, por fim, 0 a 15 anos. Analisando a frequência desses usuários na praça, conclui-se que a maioria dos usuários a utilizam três ou mais vezes na semana, seguido de pessoas que a usam raramente. Em relação à permanência, constatase que a praça é predominantemente utilizada por menos de $1 \mathrm{~h}$, reforçando ainda mais seu caráter de local de passagem. Observou-se também que os usuários moram na cidade de Teresina há bastante tempo (mais de 10 anos) e em bairros localizados próximos à praça. Por outro lado, um dado que chama atenção é que $26 \%$ dos que frequentam a praça moram em bairros distantes. A praça é considerada pelos entrevistados, bem localizada, pois o acesso ao local pode ser feito por duas avenidas e diversas ruas pavimentadas, bem como as calçadas no seu entorno. Assim, apesar da insegurança dos usuários ao utilizarem a praça, o deslocamento até o local é realizado através de diferentes formas, dentre eles, os mais usados são a pé, carro/moto e transporte coletivo (Cavalcante et al, 2016).

Na praça, há predominância em alguns pontos da concentração de pessoas observando o movimento e interagindo, como os feirantes que ficam na praça trabalhando e moradores da região que ficam conversando e/ou jogando (Figura 16). Observou-se que, durante o final da tarde e início da noite, o fluxo de pessoas é maior na praça devido à prática de esportes pela população.

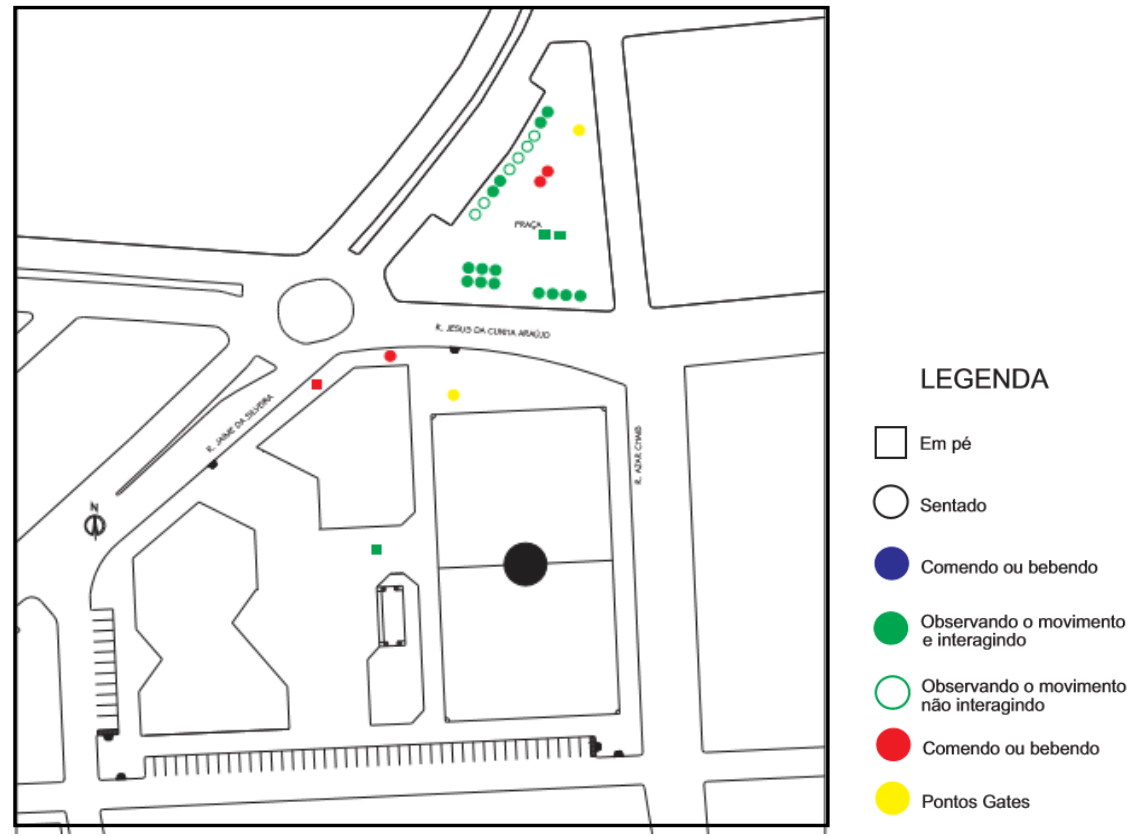

Figura 16: Mapa de pessoas paradas turno da tarde

(Pacífico et al, 2016)

A figura 17 aponta o fluxo de pessoas em dois momentos, o primeiro no dia 06/05/2016, entre 16h 03min às $18 \mathrm{~h} 00 \mathrm{~min}$, totalizando 74 pessoas, e o segundo no dia $07 / 05 / 2016$, entre $17 \mathrm{~h} 24 \mathrm{~min}$ às $18 \mathrm{~h} 35 \mathrm{~min}$, com 94 pessoas (Cavalcante et al, 2016). O fluxo existente nesses intervalos de tempo deve-se a pessoas que estão praticando atividade física, seja caminhada, corrida ou jogando futebol. É válido destacar que para prática dessas atividades, o fluxo de pessoas está concentrado nas áreas mais externas da praça, e que apesar de existir uma quadra de esporte, algumas pessoas preferem utilizar parte da grama devido problemas com o uso da quadra. Além disso, percebe-se que há um alto índice de pessoas utilizando-a como área de passagem, o que justifica o fluxo concentrado no perímetro do espaço (Cavalcante et al, 2016). 


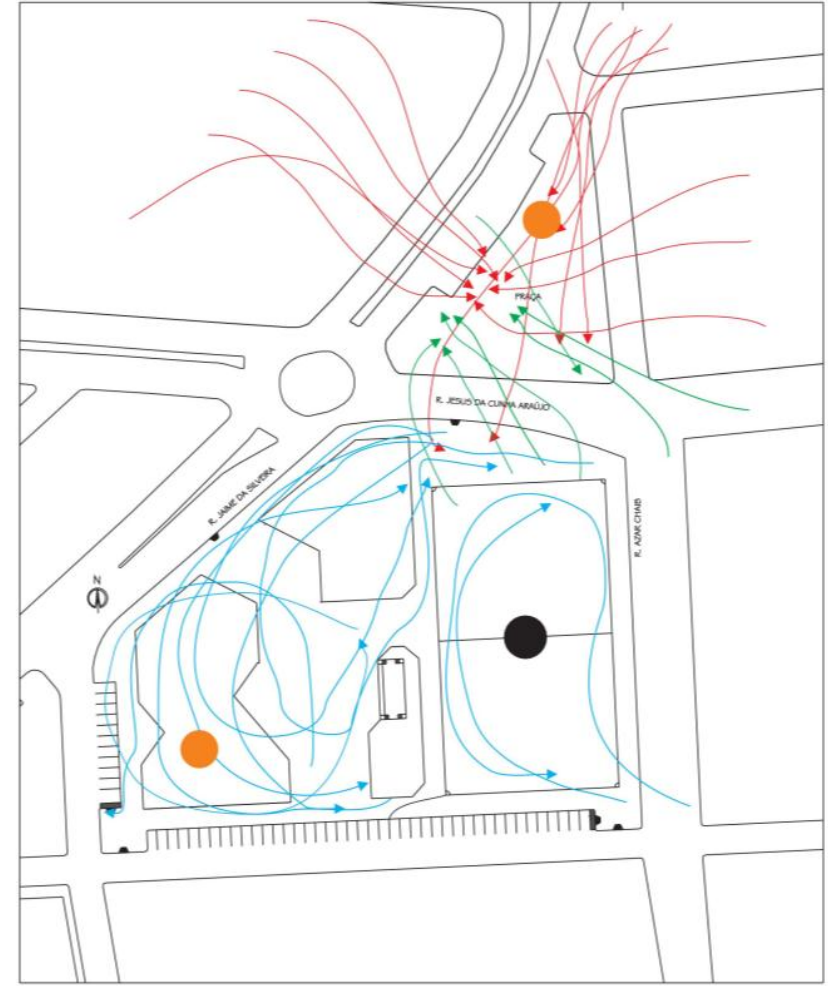

Figura 17: Mapa de fluxos turno da tarde

(Pacífico et al, 2016)
LEGENDA

$17: 30$ hs ás $17: 45 \mathrm{hs}$

$17: 50 \mathrm{hs}$ ás $18: 05 \mathrm{hs}$

18:00hs ás $18: 15 \mathrm{hs}$

Observador

O perfil do usuário é variado, o que configura a necessidade de atrativos para os mais diversos fins. Várias mudanças estruturais na praça foram sugeridas, o que demonstra a insatisfação com a acessibilidade, os equipamentos existentes e a manutenção do local. Percebe-se, dessa maneira, a subutilização da mesma, quando se considera seu potencial como espaço público, uma vez que já possui alguns equipamentos atrativos e área total considerável. Por fim, sugere-se também melhorias na iluminação pública e redução das barreiras visuais, para promover maior uso do espaço e segurança, além de adequada manutenção das áreas verdes e da quadra gramada (Cavalcante et al, 2016).

\section{CONSIDERAÇÕES FINAIS}

A praça é um espaço público urbano que propicia a apreciação da paisagem, a convivência e/ou recreação dos seus usuários, além de tornar-se parte da identidade do local onde se insere. Nesse sentido, a realização da Análise Pós Ocupacional de diferentes praças localizadas em bairros residenciais em Teresina se fez necessária para verificação da adequação ou inadequação dos espaços públicos urbanos existentes na cidade.

A partir dessa análise pode-se constatar a unanimidade da opinião dos usuários quanto à necessidade da inserção de iluminação adequada, reclamações a cerca da sensação de insegurança ao utilizarem a praça e a consequente sugestão da presença de vigias e/ou postos policiais nos locais, além da necessidade de implantação de novos equipamentos urbanos devido à pouca diversidade e/ou estado precário dos equipamentos existentes.

De acordo com o fluxo de pessoas, percebe-se que as praças são bem frequentadas diariamente, principalmente nos horários diurnos. Por outro lado, esses espaços ainda precisam de melhorias quanto à acessibilidade, pela falta de manutenção e inserção piso tátil de calçadas, implantação de rampas adequadas e vagas de estacionamento para deficientes. Além disso, melhorias das praças quanto à vegetação e projeto paisagístico foram relatadas por parte significativa dos entrevistados, muitas vezes devido à falta de arborização e diversidade de espécies vegetais, além da perceptível ausência de manutenção dos jardins. Outras questões relatadas pelos usuários, porém com menor frequência, foram a necessidade de maior diversidade de uso das praças para reduzir sua subutilização, inserção de maiores 
aberturas nas residências e uso efetivo dos terrenos vazios localizados ao seu entorno, proporcionando maior percepção visual para esses locais, além da realização constante de manutenção e conservação da praça, assim como a limpeza do espaço e coleta de lixo adequada.

Sobre as adequações e inadequações formais e espaciais verificou-se que alguns espaços não se encontram em conformidade com a apropriação social dos usurários, sendo necessário, por exemplo, modificações de acesso e desenho urbano. O presente estudo não conclui nem encerra as discussões acerca do tema mas antes acende a necessidade de se aprofundar mais nas pesquisas e nas análises dos dados apresentados de maneira a contribuir para futuras alterações nos sítios investigados.

\section{BIBLIOGRAFIA}

CAVALCANTE, A. J. P. C. et al (2016) Praça Jornalista Carlos Castelo Branco, Teresina - PI: Análises e propostas. XI Jornada Científica do Centro Universitário Uninovafapi. Os desafios atuais na construção do Saber, Teresina, 25-27 outubro.

COSTA, D. L. et al. (2016) Análise dos aspectos físicos e das condições de usabilidade do espaço público urbano, tendo como estudo de caso a Praça dos Correios. XI Jornada Científica do Centro Universitário Uninovafapi. Os desafios atuais na construção do Saber, Teresina, 25-27 outubro.

DIAS, D. A. et Al. (2016) Paisagem urbana no Espaço público: Praça Eldorado em Teresina. XI Jornada Científica do Centro Universitário Uninovafapi. Os desafios atuais na construção do Saber, Teresina, 25-27 outubro.

GOOGLE EARTH-MAPAS (2017). Disponível em://mapas.google.com. Acesso em: 13 fev. 2017.

HEITOR, T. (2011). A arquitetura da cidade: Conceitos e técnicas de análise visual.

HILLIER, B., HANSON, J. (1984). The Social Logic of Space. Cambridge: Cambridge University Press.

JACOBS, J. (2000). Morte e vida de grandes cidades. São Paulo: Martins Fontes, 2000. $1^{\text {a }}$ EDIÇÃO.

LAMAS, J. M. R. G. (2010). Morfologia urbana e desenho da cidade. sl: Fundação Calouste Gulbenkian, $5^{2}$ EDIÇÃO.

MACEDO, S. S.; ROBBA, F. (2002). Praças brasileiras. São Paulo: Edusp.

NETTO, V. M. (2013). O que a sintaxe espacial não é? Arquitextos, São Paulo, ano 14, n. 161.04, Vitruvius. Disponível em: <http://www.vitruvius.com.br/revistas/read/arquitextos/14.161/4916>. Acesso em: 08 fev. 2017.

ORNSTEIN, S. W.; BRUNA, G. C.; ROMÉRO, M. de A. (1995). Ambiente Construído e Comportamento: a Avaliação Pós Ocupação e a qualidade ambiental. São Paulo, FAU USP/Studio Nobel/FUPAM.

SOUSA, G. K. I. et al (2016) Avaliação da paisagem urbana em espaços públicos e a satisfação dos usuários na praça Dom Avelar Brandão Vilela. XI Jornada Científica do Centro Universitário Uninovafapi. Os desafios atuais na construção do Saber, Teresina, 25-27 outubro. 